\title{
CDISC SDTM Device Properties Test Code Terminology
}

National Cancer Institute

\section{Source}

National Cancer Institute. CDISC SDTM Device Properties Test Code Terminology. NCI

Thesaurus. Code C111111.

Terminology associated with the device properties test code codelist of the Clinical Data Interchange Standards Consortium (CDISC) Study Data Tabulation Model (SDT M). 